\title{
DECAPITALIZATION OF FINANCIAL SECTOR: CONSEQUENCES FOR THE ECONOMY OF UKRAINE
}

The paper reveals the conceptual basis of decapitalization of the financial sector as a phenomenon, generated by both objective and subjective factors: fundamental causes of decapitalization of the financial sector may be due to deteriorating financial conditions of borrowers and issuers and capital losses in other sectors, resulting in negative values of net savings at macro level; in the case of reduction of the rate of net savings or its negative value (with unavailability of external financing) economic system undergoes local or total decapitalization, which expands to all sectors.

The authors indicated, that the forms and methods of decapitalization of the financial sector were determined by the type of financial institution, and by the special nature of financial relations with other sectors and the related structure of assets and liabilities.

The concept of "decapitalization of the financial sector" is justified as absolute reduction of the nominal amounts of equity and equity equivalent for the financial institutions of all types less the capital of the central bank. This interpretation requires a balance approach and allows evaluating the extent of decapitalization nominally, taking no account of money depreciation due to inflation.

It is established, that decapitalization of the financial sector in Ukraine in 2014-2016 acquired the following main forms: a decrease in equity due to depreciation of debt-based financial instruments; a decrease in equity due to the depreciation of equity- debt financial instruments; a reduction of capital in connection with the termination of financial institutions;

The authors argued, that the fundamental reason of decapitalization of the banking sector were interrelated trends of depreciation and liquidity shortage, associated with the loss, by part of the banks, of their ability to fulfill obligations to depositors and creditors.

It is shown, that the main reasons of the decapitalization of the Private Pension Funds were the rapid reduction of pension contributions as a result of the poor financial state of the real sector companies, that fund programs of supplementary pension probision, as well as losses due to the depreciation of the stocks portfolios and banks`insolvency .

It was found, that the determining factors of the decapitalization of the insurance companies were the reduction of their registered authorized capital due to reduction of the number of licensed insurance companies, deteriorating financial performance (due to lower demand for insurance services, caused by the overall economic downturn), depreciation of financial assets (shares) and the loss of funds in insolvent banks, which led to increased number of loss-making insurance companies;

It was shown, that the main causes of the decapitalization of the Collective Investment Institutions (CII), operating on market principles, were the withdrawal of capital by participants of open-type CII, which coincided in time with the banking panic (early 2014), depreciation of financial assets and loss of funds in insolvent banks, suspention of the circulation of the issuers' securities on some territories (in the Crimea and in the ATO area). 
The authors defined the quantitative (nominal) amount of the decapitalization of the financial sector in Ukraine by segments. It was found, that the main negative effects of the decapitalization of the financial sector of Ukraine during 2014-2016 were the following: lack of equity to restore confidence in financial institutions, the decline in the debt financing of the real economy, higher interest rates due to the growing shortage of free financial resources on the domestic market and the failure of the financial sector to increase theirs propositions.

The authors provided an assessment of the consequences of decapitalization of the financial sector for Ukrainian economy. It was emphasized, that the lack of capital in financial institutions would remain one of the main obstacles to the recovery in equity and debt financing in the real economy, which would complicate the launch of market mechanisms of economic recovery in Ukraine.

Keywords: capital, banks, financial sector, financial corporations.

JEL: E210, E620, G320

Capital adequacy of the financial sector is one of the main pillars of the development of a country's economy and its main sector industry, undergoing now a renaissance due to the advanced development of the Industrial Internet of Things, artificial intelligence and modern cyberphysical systems [1]. The need for technological renewal and structural changes in the economy requires a rapid updating of fixed assets. So a properly capitalized financial sector is, among other factors, a prerequisite for recovery of the national economy. The poor performance of financial intermediaries (particularly in terms of loans and investments supply) reduces the rate of the intersectoral mobility of capital and preserves the current outdated structure of production.

The government cannot assume the function of the financial sector and provide in so doing a more effective redistribution of financial resources. On the contrary, in a situation where public finances are in a difficult situation, the government by excessive borrowing from the financial sector distorts the market mechanisms of resource allocation ${ }^{1}$.

Financial corporations' sector in a market economy is designed to accumulate savings of other sectors and transform them into productive capital through the mechanisms of indirect (debt or equity) financing, thereby contrib-

\footnotetext{
${ }^{1}$ In economic science it was called the "crowding out effect", when part of savings, accumulated by the financial sector, is used to "patch the holes" in the public finances [2, p. 16].
}

uting to the inter-industrial reallocation of capital. The growth of such funding is possible with the two key factors, namely - public confidence in financial institutions and availability of net savings in the household sector.

Public confidence in the financial sector, along with the influence of other factors, is based on the capital adequacy of the financial institutions, required to cover potential losses, related to active operations. The level of confidence depends on the ability of regulators to prevent frauds, and the current system of prudential supervision over financial institutions and corporate governance.

Loss of capital by financial institutions (decapitalization) may be a case of both objective and subjective factors - losses, caused by assets' ready sales during a financial crisis by financial institutions [3], bad loans (Nonperforming Loans - NLP) and securities writeoffs [4].

Some theoretical models were developed to predict the ex-post financial institutions losses during the financial crisis. The models allow to measure systemic expected shortfall (SES) of financial institutions during a systemic crisis and the probability of the financial systems as a whole going undercapitalized [5]. It was argued, that SES increases with the financial institution's leverage and with its expected loss in the tail of the system's loss distribution. 
The fundamental macroeconomic reasons of decapitalization of the financial sector ${ }^{1}$ may be the deteriorating financial condition of borrowers and capital issuers, losses in other sectors, macroeconomic expression of which may take a form of negative values of the "Net savings" indicator. In case of reduced rate or negative value of net savings with unavailability of external sources of financing, the economic system undergoes local or total decapitalization, which expands to all sectors. M. Brunnermeier and H.Pedersen argued, that the separate finacial institutions' lossess might degenerate into a downward spiral, that can spread into the financial system and cause an aggregate shortfall of capital [6].

Specific forms and methods of decapitalization of the financial sector are determined by the type of financial institution, the specific financial relations, arising with other sectors of the economy, and related structure of assets and liabilities. This fully concerns Ukraine, which is also characterized by a specific institutional environment. The latest research on the problem of decapitalization of the financial sector in Ukraine showed the institutional and macrofinancial causes of the banks undercapitalization in Ukraine [7]. V.Koziuk argued, that the fundamental reason of Ukrainian banking system undercapitalization was caused by its inability to be resistant against NPL hikes even in time of formal suitability to formal regulatory norms [8]. So he concluded, that banking regulation model in Ukraine was "blind" and unable to react adequately to institutional distortions. V. Mishchenko proved, that strengthening the financial stability of the banking sector requires implementation of the regulations, provided by Basel III as to creation of additional buffer and countercyclical bank capital [9]. S. Naumenkova et al. [10] focuses on the risks of spreading the insolvency of financial institu-

\footnotetext{
1 The notion of "decapitalization" is interpreted as absolute decrease in the nominal volumes of equity and related capital of the financial institutions less the capital of the national central bank. When investigating the decapitalization, we used exclusively the balance sheet approach without taking into account the over time depreciation of money via inflation.
}

tions to other sectors of the economy and imbalances exacerbation at the level of the financial system as a whole.

However, channels and mechanisms of the intersectoral transfer of capital shortages in Ukraine have not been explored. Also, causes of the non-bank financial institutions capital shortages in Ukraine were never studied before. Some aspects of the financial sector's decapitalization need to be clarified, taking into account the latest trends in Ukraine and the actualization of the problem of global financial instability [11]. All of these have determined the objective of this paper - the identification of specific processes of decapitalization of the financial sector in Ukraine, including the non-bank financial institutions, its macrofinancial causes and consequences for other sectors of national economy, as well as reverse effects of the financial sector's decapitalization on the economy as a whole. We pay special attention to the impact of key macrofinancial imbalances, caused by public finance deficit and nonfinancial corporations' debt ratios, as well as on the financial sector's decapitalization trends.

\section{Fundamental conditions and general trends of the decapitalization of Ukrainian financial sector}

During 2008-2013, there was a clear tendency to fall in rate of net savings (from $11.6 \%$ of GDP in 2008 to $0.8 \%$ of GDP in 2012), which meant the formation of a consumption based economic model. During the pre-crisis period and 2010-2013, the insufficient domestic savings were offset by external borrowing. Especially massive external borrowing took place in 2011-2013, which allowed to temporarily conceal the poor state of the capital accumulation in the economy (Table 1). In 2014 net savings rate was negative ($0.8 \%$ of GDP) and covered by the lending from International Monetary Fund (IMF). The higher net savings rate in 2015-2016 resulted from the squeezing of private consumption, crucial fall of household savings and the wealth redistribution on the benefit of the National Bank of Ukraine caused by the hryvna's depreciation. 
Net savings and external borrowing in 2008-2016, \% of GDP

\begin{tabular}{|l|c|c|c|c|c|c|c|c|c|}
\hline \multicolumn{1}{|c|}{ Indicator } & 2008 & 2009 & 2010 & 2011 & 2012 & 2013 & 2014 & 2015 & 2016 \\
\hline Rate of net savings & 11.6 & 4.9 & 7.6 & 6.3 & 0.8 & -3.1 & -0.8 & 4.4 & 6.0 \\
\hline Lending/borrowing & 7.1 & -0.1 & 0.1 & 4.7 & 6.0 & 6.2 & 1.5 & -1.4 & 2.4 \\
\hline Total & 18.7 & 4.8 & 7.7 & 11.0 & 6.8 & 3.3 & 0.7 & 3.0 & 8.4 \\
\hline
\end{tabular}

Source: Consolidated national accounts. Available at: http://ukrstat.gov.ua/

During 2010-2013, the national debt was rapidly increasing, and the rate of net savings was reducing. It is exactly during this period, that the macroeconomic foundations of the further decapitalization of financial sector were laid. First of all, we mean the excessive public spending, that was not backed up with corresponding revenues. The cumulative deficit of the consolidated budget for 2010-2013 alone exceeded 200 billion USD or almost $4 \%$ of GDP. Since 2009, in the general government sector, net savings were negative, and in 2013 they amounted to -54.4 billion USD, and during 2009-2013 their total amount was UAH 246 billion.

Another important factor was the impact of decapitalization in the sector of non- financial corporations, where net negative value of savings in 2013 amounted to 119.5 billion UAH (Table 2). During 2009-2013, cumulative shortage of capital in the real sector amounted to 362.7 billion USD. With the decline in the households' net savings (from 161.8 billion UAH in 2010 to 116.27 billion UAH in 2013), the shortage of capital in the economy increased, which required increasing foreign loans. Excessive government consumption and poor performance of the nonfinancial corporations were the main causes of the decline and negative rate of net savings, which reached $-3.2 \%$ of GDP, or 48.2 billion UAH in 2013.

Net savings by institutional sectors in 2005-2016, bln UAH

\begin{tabular}{|c|c|c|c|c|c|}
\hline Year & $\begin{array}{c}\text { Non-financial } \\
\text { corporations }\end{array}$ & $\begin{array}{c}\text { Financial } \\
\text { corporations }\end{array}$ & $\begin{array}{c}\text { General } \\
\text { government } \\
\text { sector }\end{array}$ & Households & $\begin{array}{c}\text { Non-commercial } \\
\text { organizations, } \\
\text { providing services } \\
\text { for the households }\end{array}$ \\
\hline 2005 & 1.88 & 10.97 & 4.59 & 45.65 & -0.27 \\
\hline 2006 & 7.15 & 14.10 & 3.82 & 44.20 & -0.55 \\
\hline 2007 & 18.27 & 24.75 & 14.09 & 47.78 & -0.75 \\
\hline 2008 & 6.13 & 39.78 & 12.21 & 52.01 & -0.57 \\
\hline 2009 & -28.64 & 52.80 & -59.43 & 80.38 & -0.56 \\
\hline 2010 & -51.25 & 37.45 & -65.65 & 161.87 & -0.11 \\
\hline 2011 & -62.29 & 43.15 & -21.33 & 123.12 & -0.06 \\
\hline 2012 & -101.01 & 10.99 & -44.80 & 147.28 & -0.14 \\
\hline 2013 & -119.54 & 10.08 & -54.37 & 116.27 & -0.74 \\
\hline 2014 & -6.66 & 26.83 & -53.21 & 30.78 & -0.24 \\
\hline 2015 & 65.03 & 9.06 & 1.32 & 12.98 & -0.45 \\
\hline 2016 & 165.98 & 15.57 & -18.60 & -17.89 & -0.11 \\
\hline
\end{tabular}

Source: Accounts of the institutional sectors of the economy. Available at: http://ukrstat.gov.ua/

In 2014-2015 the net savings' sectoral structure had changed drastically. We could observe the significant drop in the household savings from 116.3 billion UAH in 2013 to 12.98 billion $\mathrm{UAH}$ in 2015. In 2016 the household savings has gone negative. This effected the downward impact on the total net saving rate. Among others the important reason of the households savings' fall was the extremely low demand on the national curren- 
cy and the savings flight in the foreign currency estimated by SNA as net lending $(-1.4 \%$ GNP in 2015).

Before 2014, the sector of financial corporations had showed a positive rate of net savings, remaining the focus of capital accumulation in the economy. The availability of external financing before 2014 allowed mitigating the shortage of domestic funding sources, and no direct connection was observed between the rate of net savings and capital of the financial sector.

Beginning from 2014, decapitalization of the financial sector became a result of various geopolitical factors, connected with the annexation of the Crimea and beginning of the military conflict in the Southeast of Ukraine, which, in combination with the already existing cumulative macro-financial imbalances led to the loss of access to international financial markets and capital flight from Ukraine. The negative balance of payments in 2014, amounting to 13.3 billion USD, strengthened the cumulative deficit of capital and acted as a trigger for the rapid destruction of Ukrainian financial system.

Table 3 shows the volumes of the bank and non-bank financial institutions' equity and its equivalents from early 2013 to September 2017.

Equity (shares and other equity) of Ukrainian financial sector in 2013-2017,

Table 3 end of the year, million $U A H$

\begin{tabular}{|c|c|c|}
\hline Year & Bank institutions* & Non-banking financial institutions*** \\
\hline 2012 & 202399 & 226325 \\
\hline 2013 & 232103 & 249459 \\
\hline 2014 & 213554 & 261000 \\
\hline 2015 & 162090 & 264125 \\
\hline 2016 & 161246 & 242288 \\
\hline 2017 (Septemer 30) & 192199 & 259600 \\
\hline
\end{tabular}

* Deposit corporations including insolvent banks less the National Bank of Ukraine.

** Insurance companies, non-public pension funds, collective investment institutions, credit unions and other credit institutions, financial companies, legal entities, that provide financial leasing services, pawnshops and financial auxiliaries.

Statistics.xls

Source: Surveys of financial corporations. Available at: http://bank.gov.ua/files/3.1-Monetary_

After the crisis of 2008-2009, the amounts Ukrainian financial sector's capital grew. During 2013, the banks' capital increased by 30 billion UAH and that of nonbank financial institutions by 23 billion UAH. During 2014-2015, a trend of decapitalization of the financial sector emerged: initially in the banking segment and later in the sector of non-bank financial institutions.

The process of bank decapitalization started already in the first phase of decapitalization of the financial sector (early 2014), but it was not critical in scale: the capital decreased by 10.5 billion UAH, representing $4.5 \%$ of the banks' total equity as of early 2014. Non-bank financial institutions, unlike banks, had relatively small amounts of current liabilities and were less vulnerable to currency risks. The rise of capital in the non-banking financial institutions lasted until the end of the 2015 , because of the fundamentally different nature of the risks inherent in their activities ${ }^{1}$.

The main reason of the decapitalization of the financial sector was the rapid deterioration of the general economic situation under the influence of unfavorable combination of

\footnotetext{
${ }^{1}$ The excess of the amount of capital in the nonbank financial institutions over that of the banks is explained by the fact, that capital includes the net asset value of the Institutions of collective investment (ICIs) and nonpublic pension funds (NPFs). Moreover, most of them are accounted for the net assets of venture ICIs, which are overloaded with poor quality securities, account of which at fair value is not conducted. These features should be considered, when comparing the capital of these institutions with that of the banks.
} 
political and economic factors. Figure 1 shows, that the scale of decapitalization of the financial sector was the largest in late 2014 - early 2015 due to the worsening situation in the temporarily occupied territories of the East.

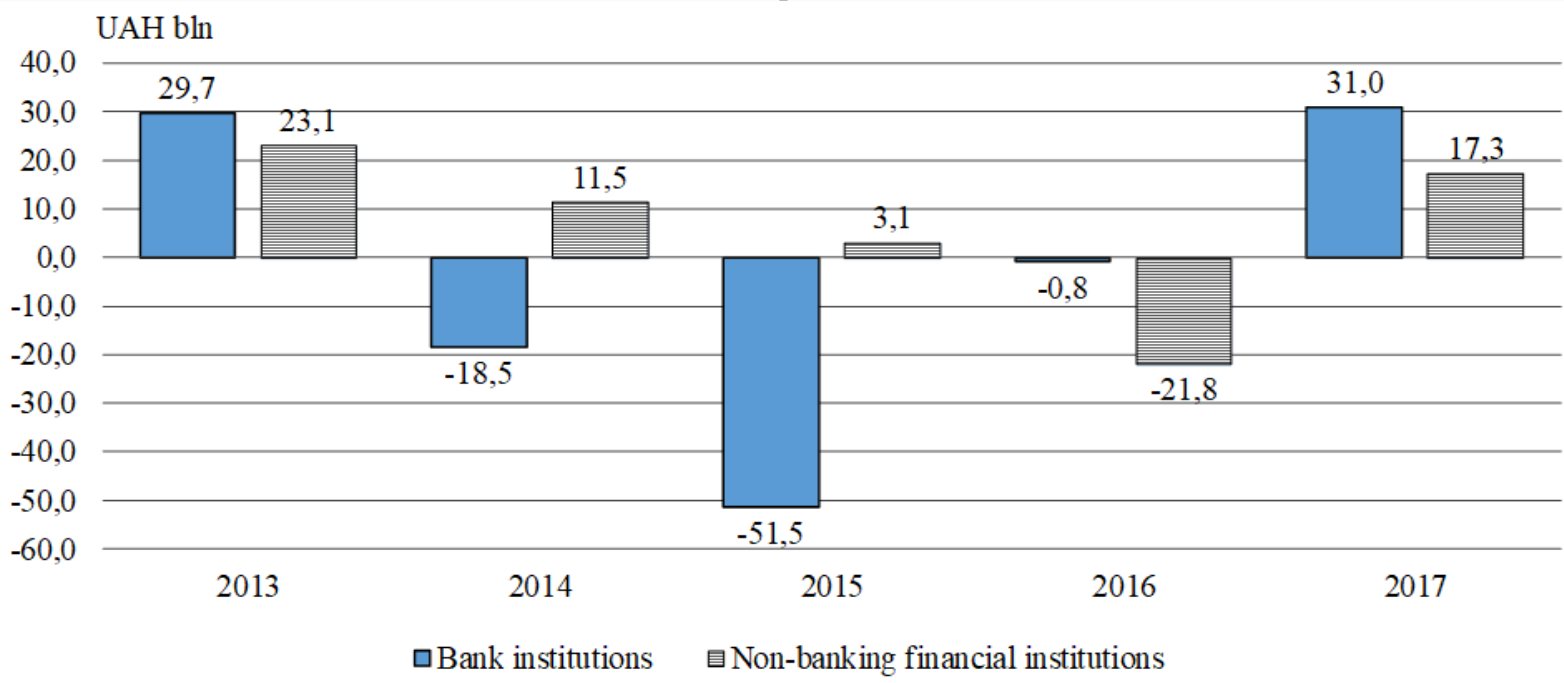

Source: Surveys of financial corporations. Available at: http://bank.gov.ua/files/3.1-Monetary_ Statistics.xls

Fig. 1. The scope of decapitalization of Ukrainian financial sector in 2014-2017

In conditions of high uncertainty and investment risks, households as the main donor of the financial sector tried to break financial relationships with banks and other financial institutions. A significant impact was caused by the devaluation of the hryvnia under the pressure of the balance of payments deficit in the first quarter of 2014 (amounting to 4.3 billion USD), which was enough to trigger the process of deleverage (withdrawal of funds) and decapitalization of the financial sector.

In a market economy the loss of liquidity is not followed by a loss of capital only in case of debt restructuring. Since the society was not ready for such restructuring, the banking panic began, when a considerable part of the depositors tried to withdraw their deposits (Fig. 1).

Specific features of the decapitalization of Ukrainian financial sector were determined by the type of financial institution, specific financial relations with other sectors, and the structure of assets and liabilities.

\section{Banks: causes and characteristics of decapitalization}

Decapitalization of the banks began in the first quarter of 2014. According to the National Bank of Ukraine (NBU), the banks' equity from early 2014 to the end of 2015 decreased by 91 billion UAH (from 192 to 101 billion) (Table 4). Given that part of the banking sector, namely - the state-owned banks, received a capital infusion of more than 20 billion UAH [12], the real extent of decapitalization can be estimated at 110 billion $\mathrm{UAH}^{1}$.

${ }^{1}$ Apart from calculating the insolvent banks, the volume of decapitalization of the "working" banks amounts to 65 billion USD, and in terms of regulatory capital - 66 billion UAH. As a result of decapitalization of the banking sector, the indicator of adequacy of regulatory capital (standard value - 10\%) decreased from $18.26 \%$ in early 2014 to $8.03 \%$ as of 08.01 .2015 . According to Investment Capital Ukraine, the banking system of Ukraine for the next three years needs a capital increase of 120 billion $\mathrm{UAH}[13]$ to restore capital adequacy. 
Capital of Ukrainian banks in 2014-2017, $\operatorname{mln} U A H$

\begin{tabular}{|l|c|c|c|c|c|}
\hline \multicolumn{1}{|c|}{ Indicator } & 01.01 .2014 & $\mathbf{0 1 . 0 1 . 2 0 1 5}$ & 01.01 .2016 & 01.01 .2017 & 01.01 .2018 \\
\hline Balace-sheet capital & 192269 & 147692 & 101560 & 124647 & 159827 \\
\hline Regulatory capital & 204976 & 188949 & 129817 & 109654 & 115818 \\
\hline $\begin{array}{l}\text { Regulatory capital to risk- } \\
\text { weighted assets , \% }\end{array}$ & 18.3 & 15.6 & 12.3 & 12.7 & 16.1 \\
\hline Financial Result & 1436 & $-52966^{1}$ & -72548 & -160143 & -25972 \\
\hline $\begin{array}{l}\text { Non-performing Loans to } \\
\text { Total Gross Loans, \% }\end{array}$ & 12,9 & 19,0 & 28,0 & 30,5 & 54,5 \\
\hline
\end{tabular}

The financial result of the banking system was negatively impacted by the losses of the banks, classified as insolvent, in which interim administrations were introduced.

* Less the banks under liquidation and those declared insolvent.

Source: Financial Soundness Indicators. Available at: http://data.imf.org/regular.aspx?key=61404590

The fundamental reason of the decapitalization of the banking sector were the interrelated trends of impairment of assets and liquidity shortages, caused by the loss of the banks' ability to meet their obligations before depositors and creditors.

1. Deterioration and impairment of assets. The main component of the assets in the banking sector are loans, which in early 2014 already had poor quality, caused by both objective (poor financial condition of borrowers) and subjective (common practice of crediting related parties) factors.

At the beginning of 2014, the level of indebtedness of the non-financial corporations sector was 1.92 and the equity deficit was estimated at 350 billion UAH, which was the amount, needed to reduce excessive indebtedness to critically acceptable 1.5 . During 20142015, general economic factors, such as falling domestic and external demand, the depreciation of the hryvnia, and loss of control over the assets in Crimea and Southeast Ukraine led to deterioration in the financial condition of nonfinancial corporations, growth of their indebtedness and worsening of the debt service capacity.

The cumulative negative financial result of the non-financial corporations before taxation for the half year (since I quarter of 2014) amounted to 1.19 trillion UAH. [3] Consolidated net loss for the period from 01.01.2014 to 01.01.2015 reached 779.2 billion UAH, accounting for $39.9 \%$ of total equity at the beginning of 2014 (1.95 trillion UAH). According to our calculations, the deficit of the companies' equity as of 01.07.2015 was estimated at be- tween 800 billion to 1 trillion UAH. Obligations for loans became more problematic. It can be stated that in 2014-2015 decapitalization of the real sector, that began in 2012-2013, spread to the financial sector.

Deteriorating of the credit quality required increase in the banks' spending on the bad debts provisions formation. While in 2013 the amount of these deductions was 26 billion UAH, in 2014 it amounted to 99 billion UAH, in 2015 - 120 billion UAH, in 2016 - 200 billion UAH. The share of Non-performing Loans in Total Gross Loans during 2014-2015 grew rapidly - from $12.9 \%$ in early 2014 to over $54 \%$ in the end of 2017, which resulted in increased banks' spending on provisions, which, from the beginning of 2014 have totaled 466 billion UAH.

One can partly agree with the opinion of the former Head of the NBU that "... the real sector is overcredited, and the banks should credit fresh and healthy working businesses, and there will be no crediting until they (the companies) increase their capital" [12], but the bank loans account for no more than $20 \%$ of the companies' total debt. Therefore, it would be more correct to speak not about the companies' overcreditness, but about their overload with accounts payable, i.e. not with liabilities to banks, but with those to other contractors. The payment crisis and lengthening debt maturities have led to a rapid increase in accounts payable. Not least, this was due to the lack of companies' liquidity, that emerged as a result of the unavailability of their funds on the accounts in insolvent banks and the growth of 
the government debt due to the overpaid corporate tax and untimely VAT refund, which total for 47 billion UAH [14]. This is the way how the decapitalization spiraled: the companies lose their funds in the insolvent banks, which meant the loss of their liquid assets, but did not reduce their liabilities to creditors.

2. The lack of liquidity and loss of the banks' capacity to fulfill their obligations to depositors. In early 2014, when the bank panic began, the companies lose their ability to service the debt and needed financial restructuring, while the households showed an abnormally high demand for cash and tried to withdraw money from banks as soon as possible. Rising geopolitical risks caused an unusually high percentage of withdrawals: during 2014 alone, the households withdrew $22 \%$ of their deposits in local currency and $40 \%$ in foreign currency.

Along with the influence of other factors, the bank panic led to technical insolvency, the introduction of interim administration and liquidation of a significant part of banks. The number of banks with banking license decreased from 180 at the beginning of 2014 to 82 on 1 January 2018 (less the insolvent banks). The amount of decapitalization, resulting from the withdrawal of insolvent banks from the market during 2014-2015, was 46 billion UAH.

\section{Non-bank financial institutions, specific features of the process of decapitalization}

Unlike the banks, decapitalization in the sector of non-bank financial institutions began later and had much lower absolute and relative volumes. While, as of early 2014, the banking sector lost almost one-third $(30.3 \%)$ of its equity, which amounted to 70.4 billion UAH, the capital of non-bank financial institutions during the same period even slightly increased by 3.5 billion UAH $(1.45 \%)$. Only the insurance companies' equity decreased - by 1.3 billion (3.3\%), while investment and nonpublic pension funds increased their net assets by $22.3 \%$ and $3.2 \%$ respectively.

This is due to the specific financial relations of the pension funds and collective in- vestment institutions with their participants. It can be concluded, that this segment of the financial sector has a relatively higher stability to the negative impact of internal and external risks, but it could not make a significant stabilizing effect on the entire Ukrainian financial sector due to a small share of the non-bank financial institutions' assets in total assets of the financial sector.

Non-public pension funds (NPFs). By the development of the level and an importance of non-public pension provision for the functioning of the mechanism of savingsinvestments transformation, Ukraine falls behind both the developed countries and neighboring countries, which have chosen the path of the civilized development, namely - Poland, Slovakia and Romania. According to the Ukrainian legislation, only the operation of funds with defined contribution, (i.e. savings funds) is permitted. Accumulating financial resources of their participants, the NPFs take no fixed liabilities and their net assets are distributed proportionally among participants. This allows to qualify the net assets of nonpublic funds as hybrid capital.

Since the specificity of non-public funds in Ukraine is due to the fact, that they are funds with defined contribution, their decapitalization (meaning decrease in their net assets value) is possible in three cases: with the growth of pension payments, with decreased revenues and with the depreciation of assets, valuated at fair value in accordance with IAS26, 32 item of which establishes that "retirement benefit plan investments shall be carried at fair value."

During 2014 - 2016, NPFs' assets structure underwent some changes, the main of which were the increase in the share of government securities from $11.5 \%$ to $40.8 \%$ and reduction of the share of Ukrainian issuers from $13.3 \%$ to $0.5 \%$ (Table 5). The bulk of the NPFs' assets is placed as bank deposits, which account for over a third of total assets. The main risks for the NPFs, with the given assets structure, are losses due to the liquidation of insolvent banks and impairment of shares, resulting from the decrease in market prices. 
Table 5

Structure of NPFs' assets in 2014-2017, \%

\begin{tabular}{|l|c|c|c|c|c|}
\hline \multicolumn{1}{|c|}{ Investment assets } & 31.12 .2013 & 31.12 .2014 & 31.12 .2015 & 31.12 .2016 & 31.12 .2017 \\
\hline Bank deposits & 36.4 & 38.6 & 39.4 & 41.3 & 43.9 \\
\hline $\begin{array}{l}\text { Government and government guaran- } \\
\text { teed securities }\end{array}$ & 11.5 & 15.3 & 34.1 & 41.0 & 40.8 \\
\hline $\begin{array}{l}\text { Bonds, issued by Ukrainian compa- } \\
\text { nies }\end{array}$ & 31.0 & 27.6 & 13.4 & 9.4 & 8.2 \\
\hline Shares, issued by Ukrainian entities & 13.3 & 10.6 & 3.3 & 0.7 & 0.5 \\
\hline Other assets & 7.8 & 7.9 & 9.8 & 7.6 & 6.6 \\
\hline
\end{tabular}

Source: Results of the development of the system of non-public pension provision as of 31.12.2017. Available at: https://www.nfp.gov.ua/files/17_Dep_Repetska/NPF_IV_kv\%202017.pdf

Until 2014, a positive dynamics of the growth of NPFs' assets had been observed, with an annual increase at $25 \%$ during 2010 2013. Since 2014 this trend has been slowing down due to the unfavorable general economic dynamics and reduced investment activities on the stock market. Although the NPFs' segment worsened the dynamics of development and accumulation of assets, but its trend of decapitalization is not very clear and not yet rampant. We can rather consider the decline in activities in this sector and decreased number of operating NPFs. While, in early 2014, the State Register of Financial Institutions contained information about $81 \mathrm{NPFs}$, on 31.12 .2017 , there were only 64 of them left. Reduction of the total number of NPFs was somewhat offset by the growth of net assets of the operating NPFs.

In 2014, the growth of NPFs' assets slowed to $18 \%$ per year, and, in 2015 , the as- sets decreased by 0.49 billion UAH, or by $19.8 \%$. The trend to decrease in NPFs' assets, which began in IV quarter of 2014, gives grounds to state a moderate decapitalization of the NPFs, which basic forms were:

- $\quad$ rapid reduction of the net pension contributions as a result of the poor financial state of main contributors (enterprises), which fund the programs of supplementary pension provision (Tab. 6). While in 2013 the volume of pension contributions amounted to 273 million $\mathrm{UAH}$, in 2014 it was 220 million UAH, and in the 2015 - only 78.6 million UAH;

- unprofitable activities, caused by the depreciation of portfolios and losses of funds in the insolvent banks. In 2015, the NPFs' losses exceeded 489 million UAH and were caused by the fall of the PFTS stock index [5] and the losses due to the liquidation of banks.

NPFs' assets and channels of their formation in 2014-2017, million UAH

\begin{tabular}{|c|c|c|c|c|}
\hline Period & Assets & $\begin{array}{c}\text { Increase in NPFs' } \\
\text { assets }\end{array}$ & $\begin{array}{c}\text { Profit from } \\
\text { assets }\end{array}$ & $\begin{array}{c}\text { Pension contributions } \\
\text { (net) }\end{array}$ \\
\hline 2012 & 1660.10 & $\mathrm{X}$ & $\mathrm{x}$ & $\mathrm{x}$ \\
\hline 2013 & 2089.80 & 429.70 & 198.0 & 273.80 \\
\hline 2014 & 2469.20 & 379.4 & 277.0 & 220.70 \\
\hline 2015 & 1980.0 & $(489.2)$ & $(438.0)$ & 78.60 \\
\hline 2016 & 2138.7 & 158.7 & 177.8 & 8.40 \\
\hline 2017 & 2465.6 & 326.9 & 349.1 & 2.10 \\
\hline
\end{tabular}

Source: Information on the condition and development of non-public pension provision in Ukraine. Available at: http://nfp.gov.ua/content/stan-i-rozvitok-npz.html 
Insurance companies. The absolute volume and relative scope of the decapitalization of insurance companies in 2014-2015 were significantly lower, than in the banking sector. This is due to the specifics of financial relations in the field of insurance, which do not involve the return of premiums to policy holders in the event of termination of the insurance contracts. In other words, the factor of liquidity shortage, caused by the bank panic, is not indicative for insurance activities, which allowed to avoid massive decapitalization in this subsector.
Total decrease in the equity of the insurance companies during 2014-2015 was 1.3 billion UAH, accounting for $3.3 \%$ of their total equity in early 2014. In the same period, total decrease in their assets amounted to 2.8 billion UAH, while the most significant reduction took place in the investment in shares (by 2.9 billion UAH) (Tab. 7).

Unlike banks, insurance companies in the first half of 2014 did not lose their capital. Decapitalization of the insurance companies intensified in late 2014 - 2016 (Fig. 2).

Table 7

The assets and equity of insurance companies in 2014-2017, million UAH

\begin{tabular}{|c|c|c|c|c|c|}
\hline Date & $\begin{array}{c}\text { Insurers' assets, } \\
\text { total }\end{array}$ & Deposits & Shares & Equity & $\begin{array}{c}\text { Authorized capi- } \\
\text { tal }\end{array}$ \\
\hline 31.12 .2013 & 66387.0 & 9296.4 & 17834.3 & 40207.6 & 15232.50 \\
\hline 31.12 .2014 & 70261.2 & 9031.8 & 18009.1 & 36176.0 & 15120.90 \\
\hline 31.12 .2015 & 60729.1 & 12603.8 & 11901.4 & 27805.0 & 14474.80 \\
\hline 31.12 .2016 & 56075.60 & 11528.60 & 7968.60 & 26881.5 & 12661.60 \\
\hline 31.12 .2017 & 57381.00 & 12238.20 & 6653.60 & 27300.8 & 12831.30 \\
\hline
\end{tabular}

Source: Results of the activities of insurance companies. Available at: http://nfp.gov.ua/files/Ogliad Rinkiv/SK/sk_\%202013.pdf; https://forinsurer.com/files/file00565.pdf; https://forinsurer.com/files/file00634.pdf

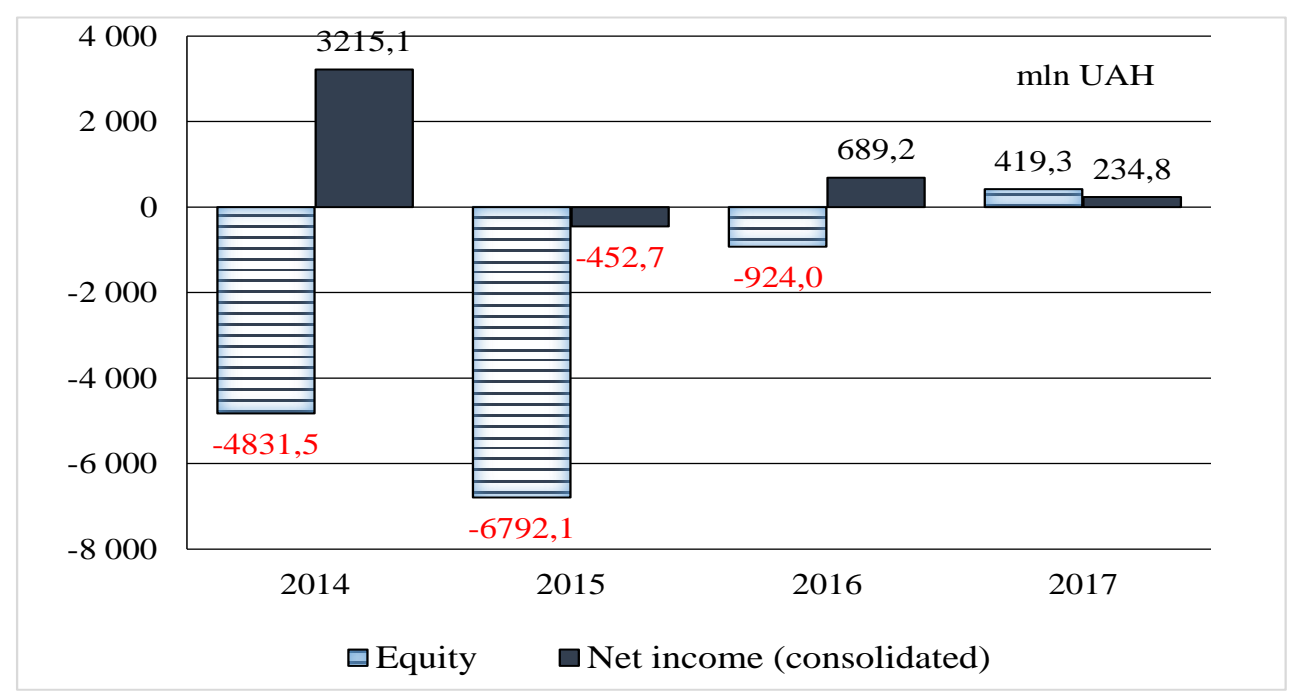

Source: Consolidated accounting data. Available at: http://nfp.gov.ua/content/konsolidovani-zvitni-dani.html

Fig.2. Changes in Equity and Financial Results of the insurance companies in 2014-2017.

During 2014, the insurance companies' equity capital decreased by 2.8 billion UAH, which accounts for $7 \%$ of this indicator at the end of the previous year. The main forms of decapitalization in the insurance segment were the following:

- reduction of the registered authorized capital by 2,4 billion UAH due to the de- 
crease in the number of licensed insurance companies, which led to a decapitalization of the insurance sector. While at the beginning of 2014 the total number of insurance companies amounted to 407, on 01.01.2017 there was 294 of them;

- deterioration of financial performance due to lower demand for insurance services, caused by overall economic downturn. In 2014, with the growth of insurance payments at 400 million UAH, premiums, received by the insurance companies, decreased by almost 2 billion UAH. The profits of the insurance sector in 2014 decreased compared to 2013 by $44 \%$;

- impairment of financial assets (shares) and the loss of funds in the insolvent banks, which led to the increase in the number of loss-making insurance companies. In 20142017 , total losses of the loss-making insurance companies were 5.5 billion UAH.

Overall, during 2014 - 2017, one can observe only moderate decapitalization in the sector of insurance companies, while the capital adequacy (ratio of equity to total assets) remained the same as at the beginning of 2014.

Institutions of collective investment (ICIs). Specifics of the financial relations in the segment of collective investment institutions is characterized by the dominance of closed-end investment funds of venture type, for which no requirements as to asset diversification are established and which are allowed to invest in bonds, promissory notes, real estate and "garbage" securities (those not allowed to trading on stock exchanges). As of 01.07.2015, out of 1171 working $^{1}$ investment funds, 1000 were venture funds, which accounted for $94.4 \%$ of net asset of the ICIs [15].

Another feature is the dominance among participants of legal entities, which as of July 1, 2015 accounted for $93.6 \%$ of the net assets of ICIs, while individuals accounted for only $6.4 \%$ of such assets. Thus, ICIs perform

1 Those, that have reached the legal minimum amount of assets (1,250 minimum monthly salaries) on the date of the registration of the fund as a collective investment institution. the function of transforming household savings into investments in relatively small volumes. The predominance of legal entities in the composition of ICIs imposed certain specificity on their activities and assets structure. The ICIs were used as a tool to avoid taxation and perform non-transparent financial transactions with securities and other financial assets.

Decapitalization (negative growth of net assets) of all the ICIs, except venture ones, only took place in the second quarter of 2014. During 2014-2017, the total net assets of ICIs increased by 86 billion UAH. At the same time the net assets of those ICIs, which are based on market principles, attracting the individuals' saving (open and interval funds), decreased by $27 \%$ and $35 \%$, respectively, or by 231 million UAH in total. The slow recovery of non-venture ICIs' sector Ukraine got only in 2017 (Tab. 8).

According to the experts of Ukrainian Association of Investment Business (UAIB), capital outflow of the depositors in the openend ICIs exceeded the decrease in net assets, which peaks took place in the first quarter of 2014. During 2015, one can observe a slowdown in net capital outflows from open ICIs, which decreased by 10 times compared to the first quarter of 2014 [16]. Although the volumes of capital withdrawals across the financial sector were generally low and could not significantly affect the volume of investment in the whole economy, but the very fact of capital withdrawal from these institutions, which even before 2014 were at an early stage of development, is an alarming signal, and a manifestation of the loss of public confidence in this type of financial intermediaries. The main forms of decapitalization of the ICIs, operating on market principles, were the following:

- capital withdrawals from the open end ICIs, which coincided in time with the banking panic of early 2014;

- impairment of financial assets and loss of funds in the insolvent banks;

- suspended circulation of securities of the issuers, located in the temporarily lost territories. 
Table 8

The value of the ICIs' net assets in 2014-2017, million UAH

\begin{tabular}{|l|c|c|c|c|c|}
\hline \multicolumn{1}{|c|}{ Fund type } & 31.12 .2013 & 31.12 .2014 & 31.12 .2015 & 31.12 .2016 & 31.12 .2017 \\
\hline Open end & 104.2 & 60.4 & 55.4 & 58.1 & 75.1 \\
\hline Interval & 126.8 & 112.5 & 88.9 & 68.1 & 82.1 \\
\hline $\begin{array}{l}\text { Closed end } \\
\text { (less venture ones) }\end{array}$ & 9108.6 & 10751.9 & 10489.9 & 7923.3 & 8364.3 \\
\hline Venture & 168183.4 & 195433.2 & 225540.9 & 222138.5 & 254957.9 \\
\hline Total Source: Quarterly and annual reviews of the ICIs market. Available at:
\end{tabular}

http://www.uaib.com.ua/files/articles/ 2660/15/Q4\%202017\%20\&\%20FY\%202017_PR.xlsx

ICIs, operating on market principles, the venture type ICIs steadily built up their net assets (the only failure was the beginning of 2014, which was the worst for the insurance companies as well). During 2014 2017 , total net assets of the venture type
ICIs increased by 86.8 billion UAH, or by $51 \%$, that can be explained by the consciously (artificially) inflated value of such funds' assets, which are dominated by "garbage" fictitious financial assets, as well as by the revival of tax evasion (Fig. 3).

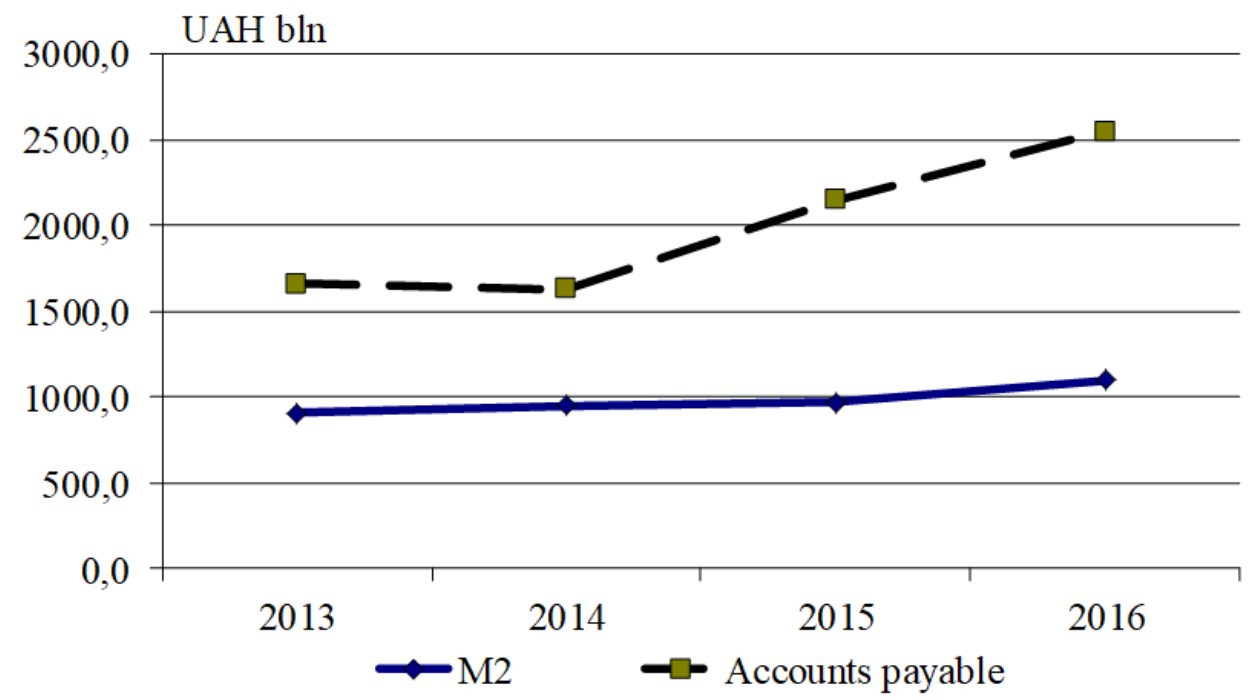

Source: Review of financial corporations. Available at: http://www.bank.gov.ua/files/3.1-Monetary_ Statistics.xls; Current liabilities and provisions by economic activities. Available at: http://ukrstat.gov.ua/

Fig. 3. Dynamics of money supply, GDP and accounts payable of the NFCs in 2014-2016 in Ukraine

Overall, during 2014-2017, one could observe only a local decapitalization in the subsectors of open-end and interval ICIs, while in the closed and venture type ICIs the value of net assets increased. Thus, the process of decapitalization caught only that part of the ICIs, that work directly with households. For the ICIs, as for the NPFs, very acute is the problem of impairment due to the loss of funds, caused by the liquidation of insolvent banks (in particular - the sequence of the satisfaction of creditors' liabilities).

\section{Forms and methods of decapitalization in Ukrainian financial sector in 2014-2017}

During 2014-2015, decapitalization in the financial sector took place in all its segments. Since 2016 the weak recovery in bank- 
ing sector and later in non-banking sector was observed, caused by the slow confidence restoration. Final data on the reduction of equity and hybrid capital of the financial institutions are presented in Table 9.

Table 9

Changes in equity and hybrid capital of Ukrainian financial institutions in 2014-2017, billion UAH

\begin{tabular}{|l|c|c|c|c|c|}
\hline \multicolumn{1}{|c|}{ Period } & $\begin{array}{c}\text { Banking } \\
\text { institutions }\end{array}$ & $\begin{array}{c}\text { Insurance } \\
\text { companies* }\end{array}$ & $\begin{array}{c}\text { ICIs less } \\
\text { venture ones } * *\end{array}$ & $\begin{array}{c}\text { Venture } \\
\text { funds** }\end{array}$ & NPFs** \\
\hline 2014 & $-44,58$ & $-4,83$ & 1,59 & 27,25 & 0,38 \\
\hline 2015 & $-44,31$ & $-6,79$ & $-0,29$ & 30,11 & $-0,49$ \\
\hline $\begin{array}{l}\text { Change for the period } \\
2014-2015\end{array}$ & $-88,89$ & $-11,62$ & 1,29 & 57,36 & $-0,11$ \\
\hline 2016 & 20,07 & $-0,92$ & $-2,58$ & $-3,40$ & 0,16 \\
\hline 2017 & 39,81 & 0,42 & 0,47 & 32,82 & 0,33 \\
\hline $\begin{array}{l}\text { Change for the period } \\
2016-2017\end{array}$ & 59,88 & $-0,50$ & $-2,11$ & 29,42 & 0,49 \\
\hline
\end{tabular}

* Equity according to financial accounting data.

** Net assets of investment and non-public pension funds.

Source: Main indicators of the activities of Ukrainian banks. Available at: http://www.bank.gov.ua/control/uk/publish/article?art_id=36807\&cat_id=36798; Quarterly and annual reviews of the ICIs' market Available at: http://www.uaib.com.ua, Results of the activities of insurance companies. Available at: http://nfp.gov.ua, Information about the condition and development of non-public pension provision in Ukraine. Available at: http://nfp.gov.ua/content/stan-i-rozvitok-npz.html

The biggest decapitalization took place in the banking sector during 2014-2015, when the aggregated sector's equity reduced by 88.9 billion UAH. In the segment of insurance companies large-scale decapitalization was observed in 2015 (equity reduction by 6.8 billion UAH). Still, compared to banks, the scope of decapitalization is explained both by specific financial relationships in the insurance sphere, which cannot be characterized as fixed liabilities and have a relatively weak level of development. Decapitalization in the NPFs' sector had limited scope and time frame: reduction of the value of net assets was observed in 2015 and amounted to 0,5 bln UAH or $20 \%$ of net assets. In the ICIs' sector, decapitalization touched only the open and interval ICIs, net assets of which reduced by 87 million UAH.

Decapitalization in Ukrainian financial sector in 2014 - 2015 took place in the following main forms.

1. Reduction of equity due to impairment of debt financial instruments. The decisive impact on the bank decapitalization is associated with the losses due to the impair- ment of loans and other debt. Due to the deteriorating financial condition of borrowers, expenditures on the banks' provisions in 20142015 were 172 billion UAH or $22 \%$ of the book value of the credits as of early 2014 . Against the background of reduced volumes of crediting, this meant that the provisions were created due to the deterioration of the borrowers' financial condition.

2. Reduction of equity due to the impairment of capital financial instruments. The impact of the impairment of capital financial instruments (due to lower capital stock index) ${ }^{1}$ of the financial sector was moderate, because the proportion of shares in the assets of financial corporations was less than $2.5 \%$ (41 billion UAH). The exceptions are the ICIs (investment in shares at the beginning of 2014 amounted to 22.6 billion USD or $14.6 \%$ of assets), insurance companies (in early 2014 investments in shares amounted to 17.8 billion UAH (27\% of assets) and NPFs (278.4 million

\footnotetext{
${ }^{1}$ In 2014 , the PFTS index grew by $28.75 \%$ and in the first half of 2015 it decreased by $21 \%$.
} 
UAH or $13.3 \%$ of assets at the beginning of 2014). Unlike the countries with welldeveloped non-bank financial sector, which is sensitive to fluctuations on the stock market, in Ukraine the factor of shares depreciation had no significant impact on the volume and dynamics of the financial sector decapitalization.

3. Reduction of capital due to the termination of financial institutions. During 2014-2015 the number of banks with banking license decreased from 180 to 117 , the number of ICIs in Ukraine decreased from 1250 to 1147 , the number of asset management companies (AMCs) declined from 347 to 313, the number of NPFs decreased from 81 to 72 , and the number of insurance companies decreased from 407 to 361 .

\section{The effects of decapitalization of the financial sector on Ukrainian economy}

The large scale decapitalization of the financial sector (especially in banking and insurance subsectors) and the slowdown in the growth of hybrid capital of the non-bank financial institutions weakened the overall sector's functional capacity to transform savings into investments. The consequences of the decapitalization were the loss of confidence to the financial institutions and reduction of the level of monetization in the economy from $53.2 \%$ to $40,5 \%$ of GDP (Tab. 10 ).

Table 10

The effects of decapitalization of the financial sector for Ukrainian economy, billion $U A H$

\begin{tabular}{|c|c|c|c|c|c|c|c|}
\hline \multirow[b]{2}{*}{ Indicator } & \multirow[b]{2}{*}{$\begin{array}{l}\stackrel{ \pm}{\circ} \\
\stackrel{+}{0} \\
\dot{0}\end{array}$} & \multirow[b]{2}{*}{ 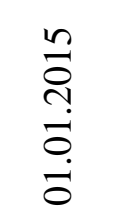 } & \multirow[b]{2}{*}{$\begin{array}{l}\stackrel{0}{0} \\
\text { in } \\
\dot{0} \\
\dot{0}\end{array}$} & \multirow[b]{2}{*}{ 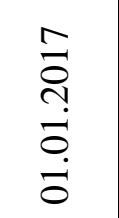 } & \multirow[b]{2}{*}{ 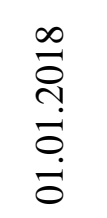 } & \multicolumn{2}{|c|}{ Change } \\
\hline & & & & & & $\begin{array}{l}\mathbb{J} \\
\vdots \\
\vdots\end{array}$ & $b^{2}$ \\
\hline Capital, including: & 451,1 & 456,9 & 450,1 & 429,2 & 489,8 & 38,7 & 8,6 \\
\hline Banks & 232,1 & 213,5 & 173,6 & 162,1 & 188,2 & $-43,9$ & $-18,9$ \\
\hline Market type ICIs & 9,3 & 10,9 & 10,6 & 8,0 & 8,5 & $-0,8$ & $-8,4$ \\
\hline Venture type ICIs & 168,2 & 195,4 & 236,0 & 230,1 & 263,3 & 95,1 & 56,6 \\
\hline Insurance companies & 39,4 & 34,6 & 27,8 & 26,9 & 27,3 & $-12,1$ & $-30,8$ \\
\hline Non-public pension funds & 2,1 & 2,5 & 2,0 & 2,1 & 2,5 & 0,4 & 17,4 \\
\hline Monetization, \% & 59,5 & 60,2 & 50,0 & 46,2 & 40,5 & & \\
\hline Interest rate on hryvnia credits, $\%$ & 15,2 & 16,7 & 21,4 & 17,7 & 15,1 & & \\
\hline Total financing of the real sector including & 778,8 & 871,5 & 854,6 & 883,3 & 872,6 & 93,8 & 5,8 \\
\hline Hryvnia credits to economic units & 454,2 & 412,9 & 338,6 & 417,4 & 455,1 & 0,9 & $-18,1$ \\
\hline Loans to legal entities in hard currency & 237,7 & 365,9 & 449,2 & 404,7 & 374,8 & 137,1 & 45,7 \\
\hline Loans to legal entities in hard currency* & 29,7 & 23,2 & 18,7 & 14,9 & 13,4 & $-16,4$ & $-29,2$ \\
\hline Shares & 43,6 & 55,2 & 39,1 & 37,0 & 28,3 & $-15,3$ & 7,5 \\
\hline Bonds & 43,3 & 37,4 & 27,7 & 24,2 & 14,3 & $-29,0$ & 8,5 \\
\hline
\end{tabular}

http://www.uaib.com.ua/files/articles/1954/21/Q1\%202014_PR.xls; Main indicators of the activities of Ukrainian banks. Available at: http://www.bank.gov.ua/control/uk/publish/article?art_id=36807\&cat_id=36798; Results of the activities of the insurance companies. Available at: http://nfp.gov.ua, Information on the condition and development of non-public pension provision in Ukraine. Available at: http://nfp.gov.ua/content/stan-i-rozvitoknpz.html

Although the nominal volumes of the financial sector's investments in the real sector increased by 94 billion UAH or by $12 \%$ (from 778.8 to 872.6 billion UAH), but the growth rate lagged significantly behind the pace of prices' growth. Given the fact that al- 
most the entire increase in the financial sector's investments in the real economy occurred only "on paper" as a result of the revaluation of foreign currency loans by 270 billion $\mathrm{UAH}$, the real volume of investments even decreased during 2014-2017. At the same time, the volume of financial institutions' investments in government bonds substantially increased by 498 UAH bln, which suggests the strengthening of the "crowding out effect" in 2014-2015.

In 2014-2017, nominal GDP, under the influence of the inflation, grew much faster than the supply of financial resources (money supply). At the same time, the companies' accounts payable grew faster, than the GDP, which means deterioration in the settlements situation in the sector of non-financial corporations (Fig. 3). While nominal money supply during this period increased by $257 \%$, the companies' accounts payable grew by $53 \%$. There was a partial replacement of the market forms of companies financing with surrogate forms, such as accounts payable, a significant part of which are overdue.

The growth of the nominal amount of the financial sector's claims to the NFCs in 2014-2016 on 105 billion UAH (Tab. 11) or by $11.2 \%$, did not exceed the rate of inflation and was a result of the revaluation of nominated in foreign currency liabilities. NFCs' sector did not receive additional resources (assets), but its liabilities grew. The stoppage of the credit and fund mechanisms of the intersectoral redistribution of resources seriously complicated the possibility of increasing the productive capital (assets) funding (be it borrowings or share issues). The dynamics of productive capital acquired all signs of a downward trend: while in 2011-2013 the annual growth of NFCs' total assets, adjusted to the inflation rate, was $6 \%$ per year, in 20142016 it was lower, than $2 \%$ per year.

Table 11

The level of development of Ukrainian financial sector in 2009-2016, bln UAH

\begin{tabular}{|l|c|c|c|c|c|c|c|}
\hline \multicolumn{1}{|c|}{ Indicator } & 2010 & 2011 & 2012 & 2013 & 2014 & 2015 & 2016 \\
\hline GDP & 1079.3 & 1300.0 & 1404.7 & 1465.2 & 1566.7 & 1988.5 & 2385.4 \\
\hline Gross savings & 197.6 & 208.4 & 198.6 & 152.6 & 164.1 & 334.9 & 457.5 \\
\hline Money supply M2 & 596.8 & 681.8 & 771.1 & 906.2 & 955.3 & 969.8 & 1102.7 \\
\hline $\begin{array}{l}\text { Increase in liabilities, } \\
\text { financial sector }\end{array}$ & 82.7 & 73.4 & 87.6 & 95.1 & 1.2 & 40.4 & 79.3 \\
\hline $\begin{array}{l}\text { Financial sector's claims } \\
\text { to NFCs, including }\end{array}$ & 680.8 & 776.1 & 846.8 & 937.8 & 1051.7 & 1040.5 & 1042.9 \\
\hline Banks' loans to NFCs & 501.0 & 575.5 & 605.4 & 691.9 & 778.8 & 787.8 & 822.1 \\
\hline NFCs' accounts payable & 1771.7 & 1910.7 & 2089.4 & 1664.3 & 1627.9 & 2148.3 & 2547.4 \\
\hline NFCs' assets & 3736.0 & 4273.3 & 4994.5 & 4824.1 & 5768.7 & 7612.3 & 9688.0 \\
\hline
\end{tabular}

Source: Review of financial corporations. Available at: http://www.bank.gov.ua/files/3.1-Monetary_ Statistics.xls; Current liabilities and provisions by economic activities. Available at: http://ukrstat.gov.ua/; Annual reports by NSSMC. Available at: http://www.nssmc.gov.ua/activities/annual/

Formal signs of the Ukrainian financial sector functional weakening were the drop of the level of monetization, followed by several other important indicators, reflecting the sector's role in the accumulation and reallocation of financial resources.

Reduction of the monetization level from $61.9 \%$ of GDP in 2013 to $48.9 \%$ of GDP in 2015 (Tab. 12) meant a weakening of the role of the financial sector in the financing of productive capital (assets in the NFCs sector), which growth rates considerably decreased, compared to the pre-war period. Along with it, the ratio of total bank credit to GDP declined (from $65.8 \%$ in 2013 to $54.1 \%$ in 2015), as well as the ratio of bank credit to domestic credit (from $80 \%$ in 2013 to $70.9 \%$ in 2015). This means, that the role of the 
banking system in the transformation of savings into investments considerably weakened. Another sign of the growing role of substitute sources against the background of the weakened financial sector was the increase in the ratio of total NFSs' accounts payable to total domestic credit: from 2.1 in
2013 to 2.94 in 2015. Also significantly weakened the role of the stock market in financing the NFCs and in overall economic development, reflected in a steep decrease: in 2015 the ratio of capitalization of the listing companies to GDP fell from $29.2 \%$ to $3.1 \%$ of GDP (almost 10 times).

Table 12

Key development ratios of Ukrainian financial sector in 2010-2016, \%

\begin{tabular}{|l|c|c|c|c|c|c|c|}
\hline \multicolumn{1}{|c|}{ Indicators } & 2010 & 2011 & 2012 & 2013 & 2014 & 2015 & 2016 \\
\hline Rate of monetization & 55,3 & 52,4 & 54,9 & 61,8 & 61,0 & 48,8 & 46,2 \\
\hline Ratio of bank credit to domestic credit & 90,0 & 87,6 & 81,4 & 77,3 & 70,0 & 67,9 & 61,5 \\
\hline Ratio of aggregate bank credit to GDP & 71,7 & 65,2 & 60,0 & 63,6 & 67,5 & 51,5 & 43,2 \\
\hline $\begin{array}{l}\text { Ratio of aggregate NFCs' accounts payable } \\
\text { to aggregate domestic credit }\end{array}$ & 228,8 & 225,6 & 247,9 & 178,6 & 153,8 & 210,0 & 247,0 \\
\hline $\begin{array}{l}\text { Ratio of the capitalization of the listing } \\
\text { companies to GDP }\end{array}$ & 15,9 & 13,7 & 19,7 & 23,7 & 29,2 & 3,2 & 0,8 \\
\hline $\begin{array}{l}\text { Ratio of cash in circulation to money aggre- } \\
\text { gate M1 }\end{array}$ & 63,1 & 61,9 & 62,9 & 62,9 & 65,0 & 59,9 & 59,3 \\
\hline $\begin{array}{l}\text { Development level of the financial sector } \\
\text { (Ft ) }\end{array}$ & 18,2 & 18,2 & 17,0 & 19,4 & 18,2 & 13,7 & 10,8 \\
\hline $\begin{array}{l}\text { Intensity of savings accumulation through } \\
\text { the financial sector }\left(\mathrm{R}^{F}\right)\end{array}$ & 41,9 & 35,2 & 44,1 & 62,3 & 0,7 & 12,1 & 17,3 \\
\hline
\end{tabular}

Source: calculated by V. Zymovets, based on data, presented in Table 10.

To estimate the role of the financial sector, the R.Vogel and S.Buser's cash ratio has also been used [17] (ratio of cash in circulation to monetary aggregate M1), which shows the relationship between the demand for cash and non-cash money, and is a measure of confidence in the banking sector under financial stability. During 2014-2016 this ratio droped from $61.9 \%$ in the early 2014 to $59.3 \%$ in the end of 2016 (Tab.12). Under financial instability and depreciation of the national currency, the stability of this ratio was a result of extremely low demand for cash in national currency.

Also, to estimate the financial corporations (FC) sector's level of development we analyzed the dynamics of the coefficient of development degree of the financial sector $\mathrm{Ft}$ (ratio of total financial claims to nonfinancial corporations to productive capital (NFCs sector's assets). During 2010-2013 this ratio had a trend to slow growth (from $18.2 \%$ to $19.4 \%$ ). In 2014 , the increase in this coefficient was related to the revaluation of foreign currency debt, and in the end of 2016 its level has dropped to $10.8 \%$. This means, that only less than one tenth of the NFCs sector's assets are financed through the financial sector in Ukraine.

To evaluate the intensity of the savings accumulation through the financial sector we apply coefficient $\mathrm{R}^{\mathrm{F}}$ derived by dividing the growth of financial sector liabilities by gross savings for the period (year). That indicator allows to evaluate the intensity of transformation of savings into sources of funding assets of the financial sector, namely - to establish, which part of the total savings for a specific period of time (a year) goes to the financial sector to create the financial resources supply. In 2010-2012 the ratio's average amount exceded $40 \%$, in $2013-60 \%$. This means, that during this period more than half of gross savings was accumulated by financial sector, which created relevant sources of the productive funding. After the outbreak of hos- 
tilities, the situation radically changed: the ratio dropped to $0,7 \%$ in 2014 and slightly upped in 2016 ( to 17.3\%). This means a three-fold reduction of the savers' confidence in the financial sector.

We underline the following key negative effects of Ukrainian financial sector's of the decapitalization in 2014 - 2016:

1. Lack of equity to restore confidence in the financial institutions. To overcome the total distrust to the financial institutions (on the part of the society as a whole and households as the main donor) the latter need a large-scale recapitalization to demonstrate the financial institutions owners' willingness to share risks with investors throughout the revival of the national financial system. The amounts, required for recapitalization, exceed the volume of the capital, that was lost during 2014-2015. Although the total decapitalization in 2014-2016 in nominal terms amounted to 21.9 billion UAH or $4.8 \%$ of the capital at the beginning of the period, by expanding them by sectors and taking into account the devaluation of the hryvnia, we can estimate the shortage of capital in the financial sector as 200 billion UAH.

2. The decline in the lending of the real sector of economy. During 2014-2016 the volume of lending in national currency fell by 37 billion UAH, or by $8.1 \%$, while lending in foreign currency decreased by 15 billion USD (equivalent). There was also a reduction in the real sector funding by bonds: total volume of investments in bonds decreased by 19 billion UAH (44.2\%). According to the National Securities and Stock Market Commission, in 2014 the volume of registered bond issues amounted to 39 billion UAH, in 2015 - 11.4 billion, in 2016 - 5,5 billion [9]. Lack of demand has led to lower activity on the market of primary placement of corporate bonds: in 2016 the volume of issue decreased by $10 \%$, in 2015 the decrease exceeded $50 \%$. The main reason of the lending decline was the lack of capital in the financial institutions to cover the existing credit risks.

3.The rise of the interest rates, caused by the growth of the deficit of financial re- sources, available on the domestic market, and the failure of the financial sector to increase their supply. The interest rate on loans in the national currency increased from $17.5 \%$ per annum at the beginning of 2014 to $21.4 \%$ per annum in the end of 2015. Deficit of free financial resources was the result not only of the growing distrust in the financial sector, but also of the increasing direct lending of the government by NBU's purchasing the government bonds. During 2014 -2016 the volume of NBU's investments in government bonds rose by 235 billion UAH, which, combined with the capital deficit in the financial sector, estimated at 200 billion UAH, allows to make a conclusion about a strengthening of the "crowding-out effect" and the prevalence of fiscal factors in the decapitalization of the financial sector.

4. Stoppage of the equity based funding formation. Before early 2014 any mechanisms of indirect equity based financing of the real economy were not developed. During 20142016 the development of non-bank financial institutions (NPFs and ICIs) slowed, as well as the growth of their net assets. During the period mentioned, the volume of the financial sector's investments in the real sector companies' shares were insignificant in macroeconomic terms (less than $3 \%$ of GDP) and dropped from 43.6 to 37.0 billion UAH, and did not play any significant role in the real sector financing through equity-based instruments.

\section{Conclusions}

In 2014-2015 a "squeezing" of Ukrainian financial sector took place, i.e. a reduction of its resource base and its role as intermediary in the transformation of savings into productive capital. The outward signs of those tendencies were: demonetization of the economy, namely - the fall of the indicator of "financial depth" from 61.9 to $48.8 \%$, and an almost three-fold reduction in the intensity of the savings accumulation through the financial sector. The latter, along with the influence of other factors (especially - the material assets' losses of capital as a result of loss of part of the national territory and due to the non-cyclic 
drop in GDP), led to a slowdown in the growth of productive capital. Considering the influence of an inflation (in terms of cost-ofliving index - CPI) [18] during the years of war, we estimate the reduction of Ukrainian productive capital by at least $5 \%$, or by 250 billion UAH in the prices of 2013.

The fundamental reasons of the decapitalization of Ukrainian financial sector were the low rate of net savings and disinvestment during 2010-2013. In early 2014 investment risks, caused by the accumulation of macrofinancial imbalances, reached a critically high level. Public awareness of the impossibility to overcome the existing imbalances by means of traditional tools of the financial policy in the face of growing political risks, including those, related to the annexation of the Crimea and the beginning of military conflict in the Southeast of Ukraine, led to a bank panic, capital flight from the country and termination of many banks and other financial institutions. The liquidity crisis, combined with the poor financial condition of the real sector, led to massive losses and decapitalization of the financial sector, which will have long-term negative consequences for the economy of Ukraine.

The lack of capital in financial institutions will remain a major obstacle to restoring the financing of the real economy through debt and equity instruments and complicate the use of market mechanisms for economic recovery in Ukraine. To solve the problem of the financial system undercapitalization will be possible only under the condition of the crucial macrofinancial imbalances' abolition and reduction of investment and credit risks through:

an elimination of general government debt burden by the implementation of the long-term public expenses prudential limits;

- strengthening the capital requirements for financial institutions, in the first place - those, concerned creation of the mandatory countercyclical capital buffers;

- mitigating the financial risks and negative impact of non-financial corporations insolvency on financial institutions performance by increasing enterprises' management responsibility for frauds, as well as shortening the length of legal procedures in case of bankruptcy of enterprises.

In particular, special attention should be paid to further research of the decapitalization problem, concerning the financial sector capital shortages forecasting, studying channels and mechanisms of theirs transfer to other sectors of economy and the development of appropriate macroprudential policy tools to prevent such shortages in the future.

\section{Literature}

1. Вишневський В. П., Князєв С. І. Як підвищити готовність промисловості України до старт-трансформацій. Наука та інновації. 2018. № 14 (4). С. 55-69. doi: https://doi.org/10.15407/scin14.04.055

2. Spencer R. W. and Yohe W. P. Crowding Out" of Private Expenditures by Fiscal Policy Actions. Federal Reserve Bank of St. Lois. October 1970. P. 13.

3. Corvasce G. The Role of Capital in Financial Institutions and Systemic Risk. SSRN Electronic Journal. November 2011. URL: https://www.banque-france.fr/sites/ default/files/media/2017/05/22/systemic-riksg-corvasce-032012.pdf. doi: http://dx.doi.org/ 10.2139/ssrn. 1957910

4. Restoring Financial Stability: How to Repair a Failed System. Viral V. Acharya and Matthew Richardson, editors. New York Stern - School of Business, John Wiley \& Sons, 2009. p. 143.

5. Acharya V. V, Pedersen L. H., Philippon T., Richardson M. Measuring Systemic Risk. July, 2016. URL: http://pages.stern. nyu.edu/ sternfin/vacharya/public_html/pdfs/ MeasuringSystemicRisk_RFS_MR_final.pdf

6. Brunnermeier M., Pedersen H. L. Market Liquidity and Funding Liquidity. Review of Financial Studies. 2009. № 22(6). P. 2201-2238. URL: https://www.princeton. edu/ markus/research/papers/liquidity.pdf. doi: https://doi.org/10.1093/rfs/hhn098

7. Даниленко А., Зимовець В., Шелудько Н. Декапіталізація фінансового сек- 
тора економіки України: причини і наслідки. Економіка та прогнозування. 2015. № 4. C. 7-28.

8. Koziuk V. Transformation of Bank Capital Regulation in Ukraine: the Role of Institutional Distortions. Financial Markets, Institutions and Risks. 2017. № 1 (4). C. 1623. doi: http://dx.doi.org/10.21272/fmir.1(4). 16-23.2017

9. Міщенко В. І. Капіталізація банківської системи України: сьогодення та перспективи. Вісник Національного банку України. 2013. № 7. С. 11-17.

10. Науменкова С., Міщенко В., Мiщенко С. Макроекономічні аспекти оцінювання достатності капіталу банків в Україні. Фінансово-кредитна діяльність: проблеми теорії та практики. 2017. Вип. 2. C. 4-16. URL: http://nbuv.gov.ua/UJRN/ Fkd_2017_2_3

11. Вишневский В.П., Шелудько Н.М. Глобальная финансовая нестабильность как «новая нормальность»: истоки, вызовы, перспективы. TERRA ECONOMICUS. 2017. T. 15. № 3. C. 3255. doi: http://dx.doi.org/10.23683/20736606-2017-15-3-32-55

12. Сколотяний Ю., Самаєва Ю. Валерія Гонтарєва: "Ці статки й ця так звана олігархія - дуті бульбашки". Дзеркало тижня. Україна. 2015. 2 жовтня. URL: http://gazeta.dt.ua/macrolevel/valeriya-gonta ryeva-ci-statki-y-cya-tak-zvana-oligarhiyaduti-bulbashki-_.html.

13. В банковскую систему нужно "влить" 120 миллиардов гривень. URL: http://ubr.ua/finances/banking-sector/v-banko vskuu-sistemu-nujno-vlit-120-milliardovgriven-354202.

14. Абромавичус анонсировал реструктуризацию 47-миллиардного долга государства перед бизнесом. URL: http://censor.net.ua/news/355356/abromavich us_anonsiroval_restrukturizatsiyu_47milliardn ogo_dolga_gosudarstva_pered_biznesoma

15. Квартальні та річні звіти. URL: http://www.uaib.com.ua/files/articles/2660/15/ Q4\%202017\%20\&\%20FY\%202017_PR.xlsx
16. УАІБ: Аналітичний огляд ринку управління активами. URL: http://www.uaib. com.ua/

17. Vogel, R., Buser, S. Inflation, Financial Repression, and Capital Formation in Latin America. Money and Finance in Economic Growth and Development. 1976. New York: Marcel Dekker, Inc., P. 35-70.

18. Изменение дефлятора валового внутреннего продукта. URL: https://ukrstat. org/operativ/operativ2014/vvp/def_vvp/def_2 014_r_n.htm

\section{References}

1. Vishnevsky, V., \& Knjazev, S. (2018). How to Increase the Readiness of Ukrainian Industry to Smart Transformations. Nauka innov., 14 (4). P. 55-69. doi: https://doi.org/ 10.15407/scin14.04.055 [in Ukrainian].

2. Spencer, R. W., \& Yohe, W. P. (1970, October). "Crowding Out" of Private Expenditures by Fiscal Policy Actions. Federal Reserve Bank of St. Lois. October. p. 13.

3. Corvasce G. (2011, November) The Role of Capital in Financial Institutions and Systemic Risk. SSRN Electronic Journal. Retrieved from https://www.banque-france. fr/sites/default/files/media/2017/05/22/systemi c-riks-g-corvasce-032012.pdf. doi: http://dx. doi.org/ 10.2139/ssrn.1957910

4. Restoring Financial Stability: How to Repair a Failed System. (2009). Viral V. Acharya \& Matthew Richardson (Eds.) New York Stern - School of Business, John Wiley \& Sons. p. 143.

5. Acharya, V. V., Pedersen, L. H., Philippon, T., \& Richardson, M. (2016, July). Measuring Systemic Risk. Retrieved from http://pages.stern.nyu.edu/ sternfin/vacharya/ public_html/pdfs/MeasuringSystemicRisk_ RFS_MR_final.pdf

6. Brunnermeier, M. K., \& Pedersen, H. L. (2009). Market Liquidity and Funding Liquidity. Review of Financial Studies, 22(6). pp. 2201-2238. Retrieved from https://www.princeton.edu/ markus/research/ papers/liquidity.pdf. doi: https://doi.org/ 10.1093/rfs/hhn098 
7. Danylenko, A., Zymovets, V., \& Shelud'ko, N. (2015). Decapitalization Of Ukrainian Financial Sector: Causes And Scale. Economy and Forecasting, 4, pp. 7-28 [in Ukrainian].

8. Koziuk, V. (2014). Transformation of Bank Capital Regulation in Ukraine: the Role of Institutional Distortions. Financial Markets, Institutions and Risks, 1(4), pp. 16-23. doi: http://dx.doi.org/10.21272/fmir.1(4).1623.2017

9. Mishhenko, V. I. (2013). Capitalization of the Ukrainian banking system: present and future. Visny`k Nacional'nogo banku Ukrayiny, 7. pp. 11-17 [in Ukrainian].

10. Naumenkova, S., Mishhenko, V., \& Mishhenko, S. (2017). Macroeconomic Aspects of Assessing Capital Adequacy of Banks in Ukraine. Finansovo-kredy'tna diyal'nist': problemy` teoriyi ta prakty 'ky`, 2. pp. 4-16. Retrieved from http://nbuv.gov.ua/UJRN/ Fkd_2017_2_3 [in Ukrainian].

11. Vishnevsky, V. P., \& Sheludko, N. M. (2017). Global financial instability as a «new normality»: Origins, challenges, prospects. TERRA ECONOMICUS, Vol. 15. No. 3. pp. 32-55 [in Russian]. doi: http://dx.doi.org/ 10.23683/2073-6606-2017-15-3-32-55.

12. Skolotianyj, Yu., \& Samaieva, Yu. (2015, October 2). Valeria Gontareva: "These States and this so-called oligarchy - inflated bubbles". Dzerkalo tyzhnia. Ukraina [Mirror

of the week. Ukraine]. Retrieved from http://gazeta.dt.ua/macrolevel/valeriya-gontaryeva-ci-statki-y-cya-tak-zvana-oligarhiyaduti-bulbashki-_.html [in Ukrainian].

13. The banking system needs to "flow" 120 billion hryvnias. Retrieved from http://ubr.ua/finances/banking-sector/vbankovskuu-sistemu-nujno-vlit-120milliardov-griven-354202 [in Russian].

14. Abromavicius announced restructuring 47-billion debt of the state to the business. Retrieved from http://censor.net.ua/news/ 355356/abromavichus_anonsiroval_restrukturi zatsiyu_47milliardnogo_dolga_gosudarstva_ pered_biznesoma [in Russian].

15. Quarterly and annual reviews of the ICIs market. Retrieved from http://www.uaib. com.ua/files/articles/2660/15/Q4\%202017\%2 0\&\%20FY\%202017_PR.xlsx

16. UAIB: Analytical review of the asset management market in 2013. Retrieved from http://www.uaib.com.ua/ [in Ukrainian].

17. Vogel, R., \& Buser, S. (1976). Inflation, Financial Repression, and Capital Formation in Latin America. Money and Finance in Economic Growth and Development. New York: Marcel Dekker, Inc., pp. 35-70.

18. The change in the deflator of gross domestic product. Retrieved from https://ukrstat.org/operativ/operativ2014/vvp/ def_vvp/def_2014_r_n.htm [in Russian].

Владислав Вікторович Зимовець, д-р екон. наук E-mail: zymovets_vlad@ukr.net;

Наталія Михайлівна Шелудько, д-р екон. наук, проф. ДУ «Інститут економіки та прогнозування НАН України» 01011, Україна, Київ, вул. Панаса Мирного, 26 E-mail: n.sheludko@ukr.net

\section{ДЕКАПІТАЛІЗАЦІЯ ФІНАНСОВОГО СЕКТОРУ: НАСЛІДКИ ДЛЯ ЕКОНОМІКИ УКРАЇНИ}

У статті висвітлено концептуальні основи декапіталізації фінансового сектору як явища, сформованого об'єктивними та суб'єктивними чинниками. Обгрунтовано поняття «декапіталізація фінансового сектору» як абсолютне зниження номінальних обсягів власного та прирівняних до нього капіталу фінансових інститутів усіх типів без урахування капіталу центрального банку країни. 
Встановлено, що основними причинами декапіталізації приватних пенсійних фондів стали різке скорочення надходжень пенсійних внесків через погіршення фінансового стану компаній реального сектору, які фінансують програми недержавного пенсійного забезпечення, а також збиткова діяльність, зумовлена знеціненням портфелів акцій та втратами коштів у непластопроможних банках.

Обгрунтовано, що визначальними факторами декапіталізації страхових компаній були зменшення зареєстрованого статутного капіталу у зв'язку зі скороченням кількості ліцензованих страхових компаній, погіршення фінансових результатів діяльності через зниження попиту на страхові послуги, зумовлене загальноекономічним спадом, знецінення фінансових активів (акцій) і втрата коштів у неплатоспроможних банках, що призвело до зростання кількості збиткових страхових компаній.

Визначено, що основними причинами декапіталізації інститутів спільного інвестування (ICI) були вилучення капіталу учасниками з ICI відкритого типу, яке співпало в часі з банківською панікою (початок 2014 р.); знецінення фінансових активів і втрата коштів у неплатоспроможних банках; призупинення обігу цінних паперів емітентів, розташованих на окупованих територіях (АР Крим та зона ООС).

Виявлено, що основними негативними наслідками декапіталізації фінансового сектору України протягом 2014-2016 рр. стали: недостатність власного капіталу для відновлення довіри до фінансових інститутів, скорочення обсягів боргового фінансування компаній реальної економіки, підвищення рівня відсоткових ставок через дефіцит вільних фінансових ресурсів на внутрішньому ринку і неспроможністю фінансового сектору збільшити їх пропозицію.

Надано оцінку наслідкам декапіталізації фінансового сектору для економіки України. Підкреслено, що дефіцит капіталу фінансових інститутів залишатиметься однією з основних перешкод для відновлення обсягів боргового та пайового фінансування реального сектору економіки, що ускладнить запуск ринкових механізмів економічного пожвавлення в Україні.

Ключові слова: капітал, банки, фінансовий сектор, фінансові корпорації.

JEL: E210, E620, G320

Владислав Викторович Зимовец,

д-р экон. наук

E-mail: zymovets_vlad@ukr.net;

Наталия Михайловна Шелудько,

д-р экон. наук, проф.

ГУ «Институт экономики и прогнозирования НАН Украины» 01011, Украина, Киев, ул. Панаса Мирного, 26

E-mail: n.sheludko@ukr.net

\section{ДЕКАПИТАЛИЗАЦИЯ ФИНАНСОВОГО СЕКТОРА: ПОСЛЕДСТВИЯ ДЛЯ ЭКОНОМИКИ УКРАИНЫ}

В статье раскрываются концептуальные основы декапитализации финансового сектора как явления, сформированного объективными и субъективными факторами. Обосновано понятие «декапитализация финансового сектора» как абсолютное сокращение номинальной стоимости собственного капитала и эквивалента капитала для финансовых учреждений всех типов за вычетом капитала центрального банка страны.

Установлено, что основными причинами декапитализации пенсионных фондов стали резкое сокращение пенсионных взносов вследствие ухудшения финансового состояния компаний реального сектора, финансирующих программы дополнительного пенсионного 
обеспечения, а также убытков, связанных с обесценением портфелей акций и неплатежеспособностью банков.

Обосновано, что определяющими факторами декапитализации страховых компаний стали сокращение их зарегистрированного уставного капитала за счет уменьшения количества лицензированных страховых компаний, ухудшение финансовых показателей из-за снижения спроса на страховые услуги, вызванного общим экономическим спадом, обесценения финансовых активов (акций) и потери средств в неплатежеспособных банках, что привело к увеличению количества убыточных страховых компаний.

Определено, что основными причинами декапитализации институтов совместного инвестирования (ИСИ) были вывод капитала участниками ИСИ открытого типа, совпавший по времени с банковской паникой (начало 2014 г.), ухудшение качества финансовых активов и потеря средств в неплатежеспособных банках, приостановление обращения ценных бумаг эмитентов, находящихся на оккупированных территориях (АР Крым и зона OOC).

Установлено, что основными негативными последствиями декапитализации финансового сектора Украины в 2014-2016 гг. являются: отсутствие доверия к финансовым институтам, снижение долгового финансирования реальной экономики, повышение процентных ставок из-за растущего дефицита свободных финансовых ресурсов на внутреннем рынке и неспособность финансового сектора увеличить их предложение.

Дана оценка последствиям декапитализации финансового сектора для экономики Украины. Подчеркивается, что нехватка капитала в финансовых институтах останется одним из основных препятствий на пути восстановления паевого и долгового финансирования реального сектора, что усложнит запуск рыночных механизмов восстановления экономики в Украине.

Ключевые слова: капитал, банки, финансовый сектор, финансовые корпорации.

JEL: E210, E620, G320

\section{Cite this publication:}

Zymovets V. V., Shelud ko N. M. Decapitalization of financial sector: consequences for the economy of Ukraine. Economy of Industry. 2018. № 3 (83). pp. 21-42. doi: http://doi.org/10.15407/econindustry2018.03.021

Zymovets, V. V., \& Shelud'ko, N. M. (2018). Decapitalization of financial sector: consequences for the economy of Ukraine. Econ. promisl., 3 (83), pp. 21-42. doi: http://doi.org/10.15407/econindustry2018.03.021 